\title{
Optimization and Production of Industrial Important Cellulase Enzyme from Penicillium citrinum in Western Ghats of Sathuragiri Hills Soil Sample Isolate
}

\author{
S. Muthukrishnan \\ Department of Biotechnology, Ayya Nadar Janaki Ammal College (Autonomous), India
}

Copyright $(2017$ by authors, all rights reserved. Authors agree that this article remains permanently open access under the terms of the Creative Commons Attribution License 4.0 International License

\begin{abstract}
In optimization of cellulase production by different $\mathrm{pH}$, substrates, nitrogen, carbon sources were detected from penicillium citrinum micro-fungal species. The maximum cellulase activity was recorded in the range of $\mathrm{pH}-5$ to 6.5 and wheat bran $(91 \mathrm{U} / \mathrm{ml})$ and rice bran $(81 \mathrm{U} / \mathrm{ml})$ is the best raw substrate for the production of cellulase. Estimation of extracellular protein was recorded in different production medium of Penicillium citrinum $(1.63$ $\mathrm{mg} / \mathrm{ml}$ ) for maltose followed by sucrose $(1.46 \mathrm{mg} / \mathrm{ml})$, fructose $(1.13 \mathrm{mg} / \mathrm{ml})$, wheat bran $(1.12 \mathrm{mg} / \mathrm{ml})$, peptone $(0.88 \mathrm{mg} / \mathrm{ml})$ and yeast extract $(0.82 \mathrm{mg} / \mathrm{ml})$. The highest extracellular protein was recorded in $\mathrm{pH} 5.5$ to 6.5 followed by substrate for wheat bran $(1.12 \mathrm{mg} / \mathrm{ml})$, rice bran $(1.04$ $\mathrm{mg} / \mathrm{ml})$, paddy straw $(1.03 \mathrm{mg} / \mathrm{ml})$. In nitrogen sources, ammonium sulphate $(141 \mathrm{U} / \mathrm{ml})$ and ammonium nitrate $(121$ $\mathrm{U} / \mathrm{ml}$ ) is the best nitrogen source for the production of cellulase enzyme. The maximum cellulase activity was recorded in glucose $(134 \mathrm{U} / \mathrm{ml})$ and maltose $(159 \mathrm{U} / \mathrm{ml})$ was best carbon source for the production of cellulase.
\end{abstract}

Keywords Cellulase, Penicillium citrinum, Optimization, Micro-fungal Enzyme

\section{Introduction}

Microorganisms play an important role in natural biodegradation processes in which plant lignocellulosic materials are efficiently degraded by cellulolytic fungi. Fungi play an important role in bioconversion and composting of organic waste and can be an important contributor to optimal agricultural and forest waste bioconversion [1]. In biological processes, aerobic microorganism biodegrade complex cellulose solid waste into simple compound such as $\mathrm{C}, \mathrm{N}, \mathrm{H}$ and mineral salts. The ability to secrete large amount of extracellular protein is a characteristics of certain fungi and such strains are most suited for production of higher level of extracellular cellulases. Among microorganisms, fungi are of great interest for enzyme production because they excrete their enzymes extracellularly [2]. Today, the new potential of using microorganisms as biotechnological sources of industrially relevant enzymes has stimulated renewed interest in the exploration of extracellular enzymatic activity in several microorganisms [3]. Selection of the right organism plays a key role in high yield of desirable enzymes [4]. Fungi are microorganisms which are well known for their wide range of novelty of enzymes they produce and enzymes of fungal origin are used in the industrial process for which, amount to billions of dollars of revenue annually [5].

The cellulolytic system of aerobic fungi and bacteria consists of three types of cellulases such as Endoglucanases, Exoglucanases and B- Glucosidases. Cellulase is a consortium of hydrolytic enzyme capable of hydrolysing cellulose in to simple glucose units. Several studies were carried out for the isolation and identification of the cellulolytic fungi possessing activity $[6,7]$. The ability of cellulolytic microorganisms to degrade cellulose varies greatly with the physico-chemical characteristics of the substrate, such as: (a) the size and permeability of cellulolytic enzymes and other reagent molecules, which are involved in relation to the size and surface properties of the grown fibrils and the space between microfibrils and cellulose molecules from amorphous region; (b) the degree of crystallinity of cellulose; (c) the unit cell dimensions of cellulose; (d) the stereoscopic conformation and rigidity of the anhydroglucose units; (e) the degree of polymerization of cellulose molecules; (f) the nature of components with which cellulose is associated; ( $g$ ) the nature, concentration and distribution of substituted groups [8]. The crystallinity degree of cellulose is one of the most important structural parameters which affect the rate of enzymatic degradation by hydrolysis. Therefore, the rate of degradation should be a function of the surface properties of cellulose which makes 
possible the access of enzymes to polymeric molecules [9].

Cellulolytic enzymes play an important role in natural biodegradation processes in which plant lignocellulosic materials are efficiently degraded by cellulolytic fungi, bacteria, actinomycetes and protozoa. In industry, these enzymes have found novel applications in the production of fermentable sugars and ethanol [10,11, and 12], organic acids [13] detergents and other chemicals [14]. They have been used in the pulp and paper industry, e. g., in deinking of fiber surfaces and in improving pulp drainage $[15,16]$ in the textile industry $[17,18]$ animal feed and even in the food industry $[19,20]$ for the processing of paper and cellophane, as well as for biotransformation of waste cellulose to fermentable sugars [21]. As lytic enzymes, they are of prime importance and are the protoplast production [22]. The demand for more thermostable, highly active and specific cellulases is on the increase. Fungi are well-known agents of decomposition of organic matter in general and cellulose substrates in particular [23]. Fungal cellulases are inducible enzymes that are usually excreted into the environment and depend on cellulose type (amorphous or crystalline) acting on the organism [24]. The objects of the present work is to identify the fungal strains Penicillum citrinum have potential for cellulose production, and compare enzyme production during varying incubation time and different substrate, carbon and nitrogen source by submerge fermentation technology.

\section{Materials and Methods}

\section{Sampling Site}

The leaf litter soil samples were collected out in Sathuragiri Hills (Western Ghats, Tamil Nadu) which is about $15 \mathrm{Kms}$ from Srivilliputhur. The town is situated on latitude 9.7273" North and longitude 77.6186" East. The town is about 4500 feet above the sea level.

\section{Sample Collection}

Soil and litter samples were collected in Sathuragiri Hills in 12 different locations (Western Ghats, Tamil Nadu). Using a sterilized spatula, $50 \mathrm{~g}$ of soil sample was collected from each location using sterile zip cover. The samples from the 12 different sites were conveyed to the Microbiology Laboratory within same day, where they were analyzed.

\section{Isolation from Serial Dilution Technique}

Soil and litter sample was mixed thoroughly in $99 \mathrm{ml}$ of sterile water in a glass tube and shaken thoroughly. From this initial suspension, serial dilutions were prepared .One $\mathrm{ml}$ of the required dilution $(1 / 1000)$ was pipette into five replicate plates containing potato dextrose agar medium with antibiotic. The plates were incubated at room temperature in glass chambers under aseptic conditions for 4 days and then examined for fungal growth.

\section{Morphological Identification of Fungi}

Lactophenol and Lactophenol cotton blue stain (Hi Media laboratories private limited) were used as the staining solution. Slides prepared were sealed with DPX mountant. Identification of the fungal species was done using "The Genera of Hyphomycetes from soil" by [25] Compendium of soil fungi by [26].

\section{Screening of Cellulase Enzymes}

The fungal isolates were screened for cellulase activity was carried out on agar media in petri plates containing the respective substrates. . The following substrate was used, for cellulase production $1 \%$ carboxy methyl cellulose (CMC) and supplemented with $1 \%$ yeast extract and malt extract, agar- $2 \mathrm{~g}$. The cultures were spot inoculated at the center of the plate and incubated at $28^{\circ} \mathrm{C}$ for a period of 5 days to get good growth of the cultures. For cellulase, the plates were flooded with an aqueous solution of $0.1 \%$ Congo red. After 30 minutes, the plates were repeatedly washed with $1 \mathrm{M}$ sodium chloride and zone of clearance around their growing margin indicated cellulase activity [27].

\section{Production Medium of Cellulase Enzyme}

To prepare the production medium of cellulase using CMC (Carboxy methyl cellulase)- 1g, yeast extract- $1 \mathrm{~g}$, glucose- $1 \mathrm{~g}$ and autoclaved to add basal mineral salt medium. Then 5-7 days fungal culture was inoculated into the all flask. The flasks were incubated at $28^{\circ}$ cin a shaker for 7 days [28].

\section{Quantitative Assay of Cellulase}

Cellulase activity was measured by the DNS (3, 5-dinitrosalicylic acid) method [29] through the determination of the amount of reducing sugars liberated. Glucose was used as a standard; $0.5 \mathrm{ml}$ of extract was reacted with phosphate buffer ( $\mathrm{pH}$ 5). Reaction was stopped by the addition of DNS solution. The reaction mixture was boiled for $10 \mathrm{~min}$, cooled in water for color stabilization, and the optical density was measured at $540 \mathrm{~nm}$.

\section{Estimation of Protein by Lowry's Method}

One $\mathrm{ml}$ of partially purified protein solution was taken in a test tubes and $2 \mathrm{ml}$ of alkaline copper sulphate reagent (analytical reagent) was added, mixed and incubate at room temperature for 10 mins. Then $0.2 \mathrm{ml}$ of reagent FolinCiocalteaus solution (reagent solutions) was added to each tube and incubated for $30 \mathrm{~min}$. Zero the UV -spectrometer with blank and take the optical density (measure the absorbance) at $660 \mathrm{~nm}$. The absorbance plotted 
against protein concentration to get a standard calibration curve. By using the absorbance of unknown sample, the concentrations of the unknown sample were determined using Bovine serum albumin (BSA) standard curve [30].

\section{Optimization of Cellulase Production by Different Carbon Sources}

The production medium of cellulase using various carbon sources namely, fructose, glucose, sucrose, lactose and maltose used for optimized the production rate. The broth contained $1.0 \%$ of each carbon sources, 1\% CMC (carboxy methyl cellulose) and was autoclaved to add basal mineral salt medium. The fungal cultures were inoculated into all flasks. The flasks were incubated at 7 days for $28^{\circ} \mathrm{c}$ in a shaker [32].

\section{Optimization of Cellulase Enzyme Production by Different Nitrogen Sources}

The production medium of cellulase using various nitrogen sources namely, ammonium nitrate, ammonium sulphate, peptone, yeast extract and sodium nitrate used for optimized the production rate. The broth contained $1.0 \%$ of each nitrogen sources, 1\% CMC (carboxy methyl cellulose) and was autoclaved to add basal mineral salt medium. The fungal cultures were inoculated into all flasks. The flasks were incubated at 7 days for $28^{\circ} \mathrm{c}$ in a shaker at $200 \mathrm{rpm}$ [32].

\section{Optimization of Cellulase Enzyme Production by Different pH}

The production medium of cellulase using substrate $1 \%$ CMC (carboxy methyl cellulase) with carbon source and nitrogen sources were added to optimized the production rate. Each flask was adjusted to different $\mathrm{pH}$ such as 5.0, 5.5, 6.0, 6.5, 7.0 using $0.1 \mathrm{~N} \mathrm{NaOH}$ and $0.1 \mathrm{~N} \mathrm{HCL}$. Then add autoclaved basal mineral salt medium. The fungal cultures were inoculated into all flasks. The flasks were incubated up to 7 days for $28^{\circ} \mathrm{c}$ in a shaker at $200 \mathrm{rpm}$ [32].

\section{Optimization of Cellulase Enzyme Production by Different Substrate}

The production medium of cellulase using different substrate namely, wheat bran, rice bran, paddy straw, paddy husk and crud paper used for optimized the production rate. The broth contained $1.0 \%$ of each substrate, and suitable carbon and nitrogen sources were added. Then add autoclaved basal mineral salt medium. Fungal cultures were inoculated into all flasks. The flasks were incubated for 7 days at $28^{\circ} \mathrm{c}$ in a shaker at $200 \mathrm{rpm}$ [32].

\section{Results}

\section{Micro-fungal Species Isolate and Cellulase Screening}

The micro-fungal species Fusarium oxysporum, Curvularia lunata, Alternaria alternate, Aspergillus niger, Cladosporium cladosporioides, Penicillium citrinum, Aspergillus nidulans were recorded in Potato dextrose Agar medium but screening of cellulase production in carboxymethyl cellulose plate assay medium in highest zone of clearance, were recorded in after floated with Congo red solution in $4^{\text {th }}$ day of micro-fungal culture plate of Penicillium citrinum (fig-1, 2). Further cellulase assays were carried out by selected micro-fungal species Penicillium citrinum.

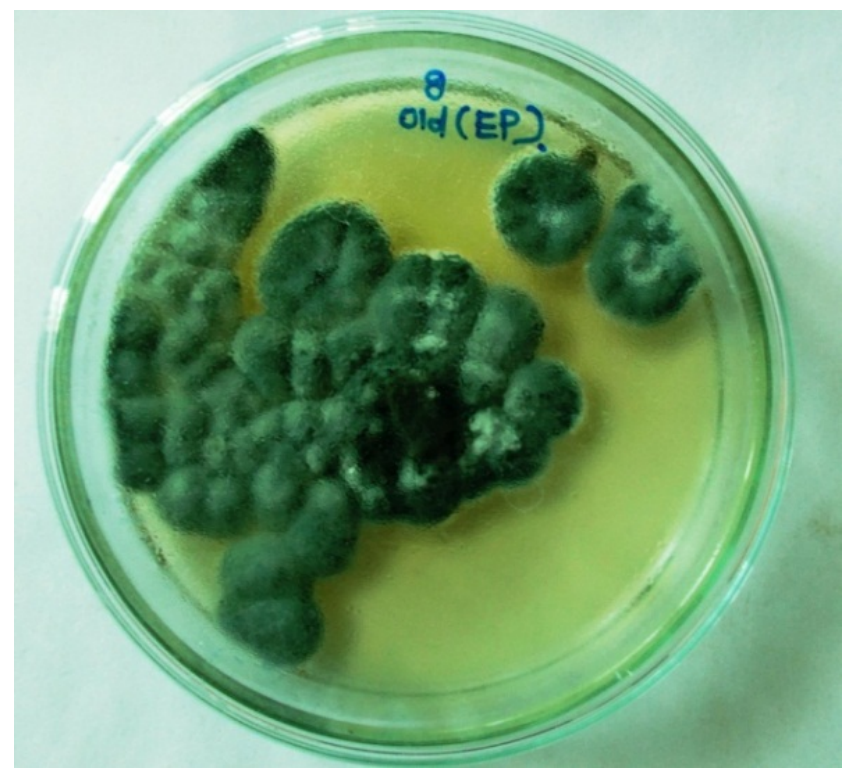

Figure 1. PDA Plate isolation of Penicillium citrinum

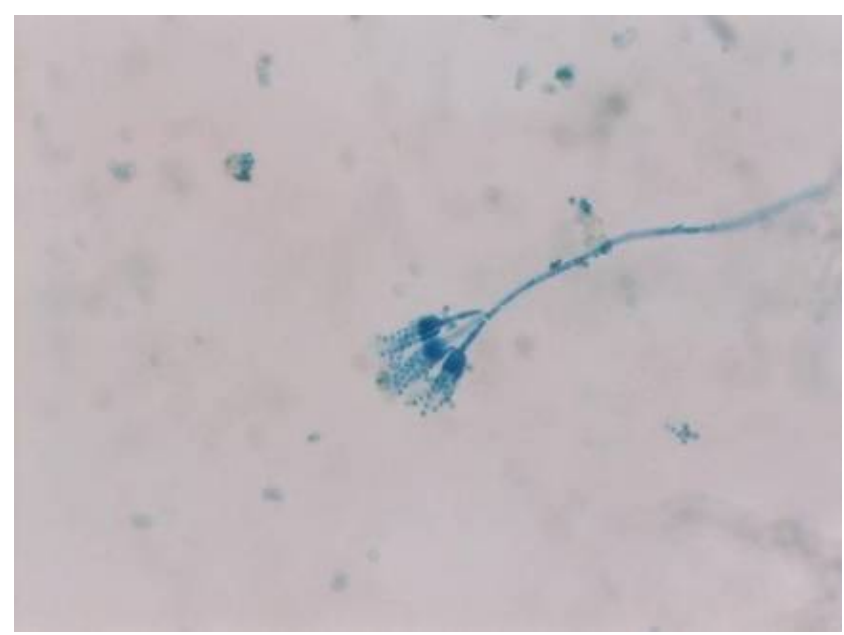

Figure 2. Penicillium citrinum Microscopic observation 


\section{Cellulase Activity of Penicillium citrinum in Different Carbon Sources}

The fungal cellulase activity was recorded in $3^{\text {rd }}, 5^{\text {th }}$ and $7^{\text {th }}$ day of fungal culture broth and the highest fungal cellulase activity was recorded in $5^{\text {th }}$ day. The maximum cellulase activity was recorded in $5^{\text {th }}$ day maltose $(159 \mathrm{U} / \mathrm{ml})$ followed by glucose $(134 \mathrm{U} / \mathrm{ml})$, sucrose $(123 \mathrm{U} / \mathrm{ml})$, fructose $(95$ $\mathrm{U} / \mathrm{ml})$ and lactose $(83 \mathrm{U} / \mathrm{ml})$. Similarly maximum cellulase activity was recorded in $3^{\text {rd }}$ day glucose $(78 \mathrm{U} / \mathrm{ml})$ followed by maltose $(70 \mathrm{U} / \mathrm{ml})$, sucrose $(65 \mathrm{U} / \mathrm{ml})$, fructose $(52 \mathrm{U} / \mathrm{ml})$ and lactose $(49 \mathrm{U} / \mathrm{ml})$. Minimum cellulase activity was recorded in $7^{\text {th }}$ day glucose $(54 \mathrm{U} / \mathrm{ml})$ followed by sucrose $(52 \mathrm{U} / \mathrm{ml})$, maltose $(51 \mathrm{U} / \mathrm{ml})$, fructose $(46 \mathrm{U} / \mathrm{ml})$ and lactose (37 U/ml) (Fig -3).

\section{Extra Cellular Protein Estimation of Penicillium citrinum for Different Carbon Sources}

The estimation of extra cellular protein were recorded in $3^{\text {rd }}, 5^{\text {th }}$ and $7^{\text {th }}$ day of fungal culture broth and the highest extra cellular protein were recorded in 5th day. The maximum amount of extra cellular protein were recorded in $5^{\text {th }}$ day maltose $(1.63 \mathrm{mg} / \mathrm{ml})$ followed by glucose $(1.58$ $\mathrm{mg} / \mathrm{ml})$, sucrose $(1.46 \mathrm{mg} / \mathrm{ml})$, fructose $(1.13 \mathrm{mg} / \mathrm{ml})$ and lactose $(1.03 \mathrm{mg} / \mathrm{ml})$. Similarly maximum amount of extra cellular protein were recorded in $3^{\text {rd }}$ day glucose $(0.97 \mathrm{mg} / \mathrm{ml})$ followed by maltose $(0.92 \mathrm{mg} / \mathrm{ml})$, sucrose $(0.89 \mathrm{mg} / \mathrm{ml})$, fructose $(0.71 \mathrm{mg} / \mathrm{ml})$ and lactose $(0.65 \mathrm{mg} / \mathrm{ml})$. The minimum amount of extra cellular protein were recorded in $7^{\text {th }}$ day glucose $(0.78 \mathrm{mg} / \mathrm{ml})$ followed maltose $(0.72 \mathrm{mg} / \mathrm{ml})$, sucrose $(0.63 \mathrm{mg} / \mathrm{ml})$, fructose $(0.62 \mathrm{mg} / \mathrm{ml})$ and lactose $(0.45 \mathrm{mg} / \mathrm{ml})$ (Fig -4).

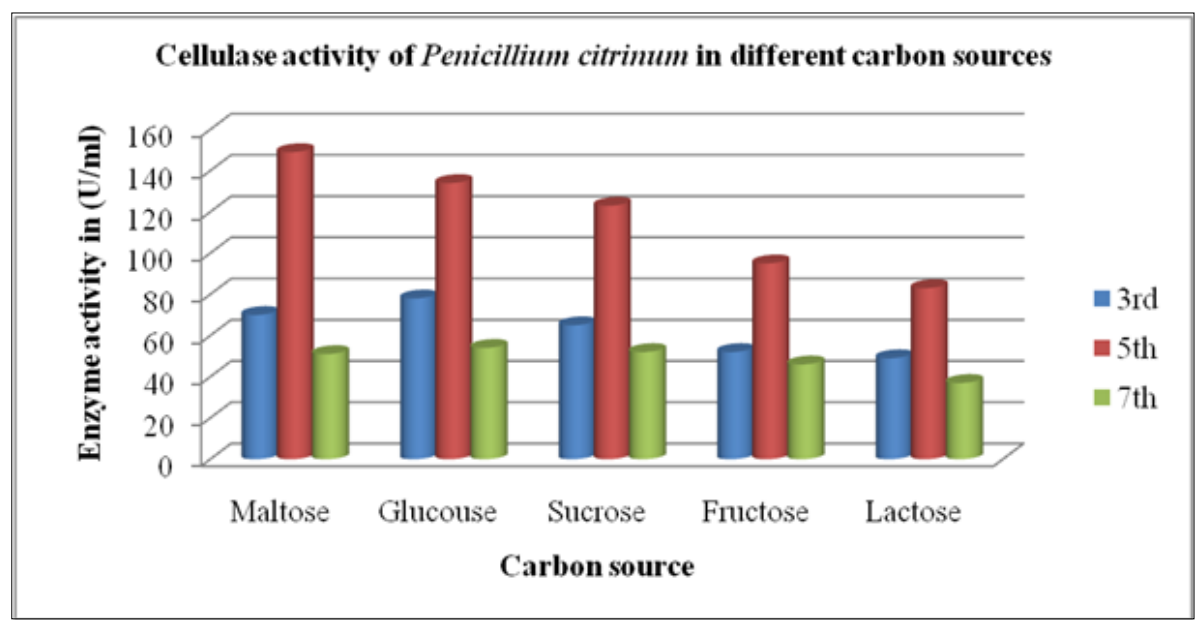

Figure 3. Cellulase activity of Penicillium citrinum in different carbon sources

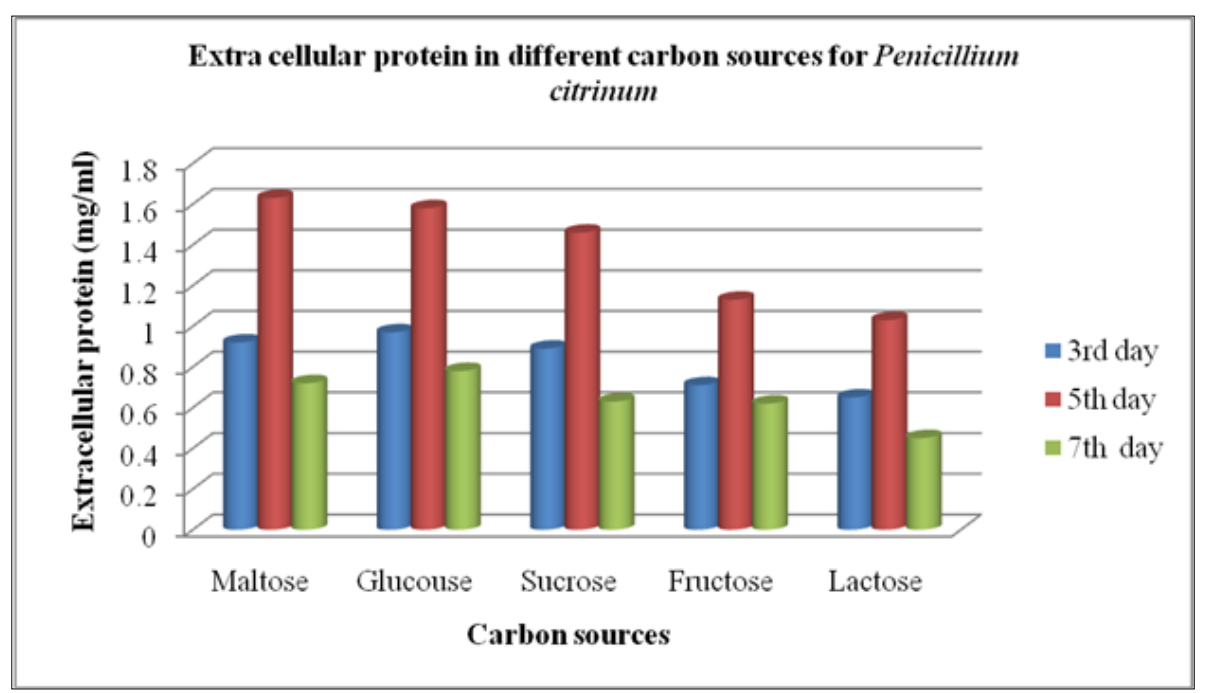

Figure 4. Extra cellular protein in different carbon sources for Penicillium citrinum 


\section{Cellulase Activity of Penicillium citrinum in Different Nitrogen Sources}

The fungal cellulase activity was recorded in $3^{\text {rd }}, 5^{\text {th }}$ and $7^{\text {th }}$ day of fungal culture broth and the highest fungal cellulase activity was recorded in $5^{\text {th }}$ day. The maximum cellulase activity was recorded in $5^{\text {th }}$ day ammonium sulphate (141 $\mathrm{U} / \mathrm{ml}$ ) followed by ammonium nitrate $(121 \mathrm{U} / \mathrm{ml})$, peptone $(112 \mathrm{U} / \mathrm{ml})$, yeast extract $(98 \mathrm{U} / \mathrm{ml})$ and sodium nitrate $(72$ $\mathrm{U} / \mathrm{ml}$ ). Similarly maximum cellulase activity was recorded in $3^{\text {rd }}$ day peptone $(78 \mathrm{U} / \mathrm{ml})$ followed by ammonium sulphate $(71 \mathrm{U} / \mathrm{ml})$, yeast extract $(69 \mathrm{U} / \mathrm{ml})$, ammonium nitrate $(68$ $\mathrm{U} / \mathrm{ml}$ ) and sodium nitrate $(54 \mathrm{U} / \mathrm{ml})$. Minimum cellulase activity was recorded in $7^{\text {th }}$ day ammonium nitrate $(64 \mathrm{U} / \mathrm{ml})$ followed by ammonium sulphate $(59 \mathrm{U} / \mathrm{ml})$, peptone $(58$ $\mathrm{U} / \mathrm{ml})$, yeast extract $(49 \mathrm{U} / \mathrm{ml})$ and sodium nitrate $(41 \mathrm{U} / \mathrm{ml})$ (Fig -5).

\section{Extra Cellular Protein Estimation of Penicillium citrinum for Different Nitrogen Sources}

The estimation of extra cellular protein were recorded in $3^{\text {rd }}, 5^{\text {th }}$ and $7^{\text {th }}$ day of fungal culture broth and the highest extra cellular protein were recorded in 5th day. The maximum amount of extra cellular protein were recorded in $5^{\text {th }}$ day peptone $(0.88 \mathrm{mg} / \mathrm{ml})$, yeast extract $(0.82 \mathrm{mg} / \mathrm{ml})$, ammonium sulphate $(0.78 \mathrm{mg} / \mathrm{ml})$, ammonium nitrate $(0.64$ $\mathrm{mg} / \mathrm{ml})$ and sodium nitrate $(0.64 \mathrm{mg} / \mathrm{ml})$. Similarly the maximum amount of protein was recorded in $3^{\text {rd }}$ day ammonium sulphate $(0.61 \mathrm{mg} / \mathrm{ml})$ followed by peptone $(0.59$ $\mathrm{mg} / \mathrm{ml})$, yeast extract $(0.56 \mathrm{mg} / \mathrm{ml})$, ammonium nitrate $(0.55$ $\mathrm{mg} / \mathrm{ml})$ and sodium nitrate $(0.42 \mathrm{mg} / \mathrm{ml})$. The minimum amount of extra cellular protein was recorded in $7^{\text {th }}$ day peptone $(0.64 \mathrm{mg} / \mathrm{ml})$ followed by yeast extract $(0.55 \mathrm{mg} / \mathrm{ml})$, ammonium sulphate $(0.50 \mathrm{mg} / \mathrm{ml})$, sodium nitrate $(0.49$ $\mathrm{mg} / \mathrm{ml})$ and ammonium nitrate $(0.37 \mathrm{mg} / \mathrm{ml})$ (Fig -6).

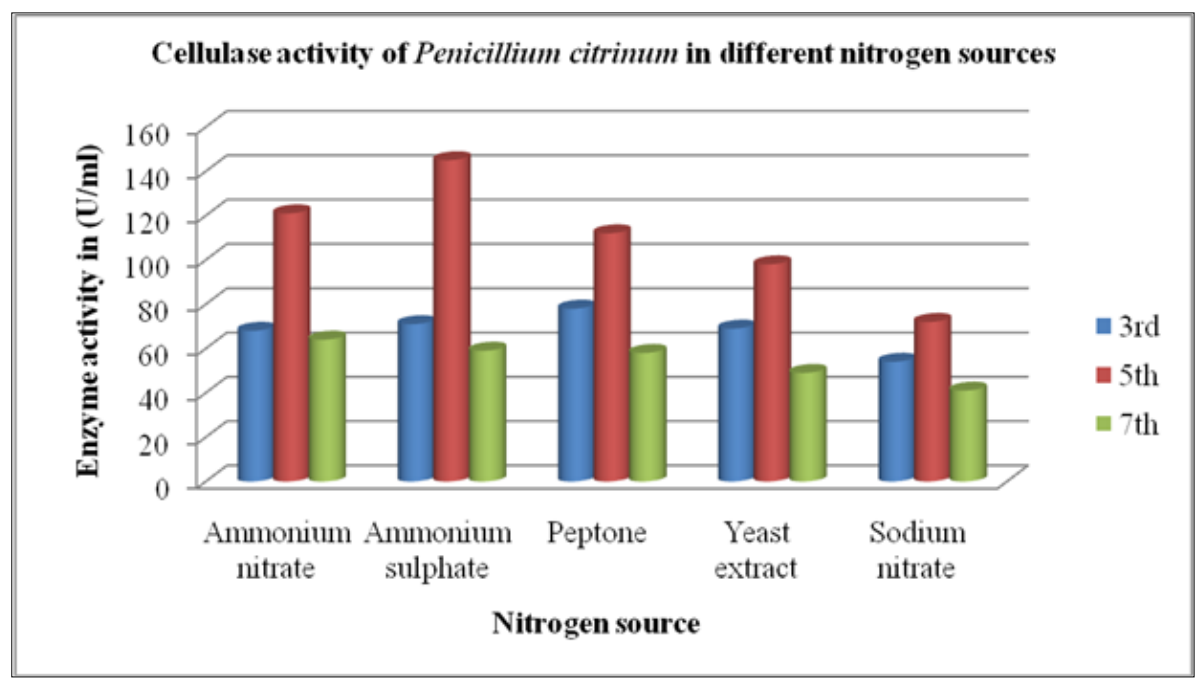

Figure 5. Cellulase activity of Penicillium citrinum in different nitrogen sources

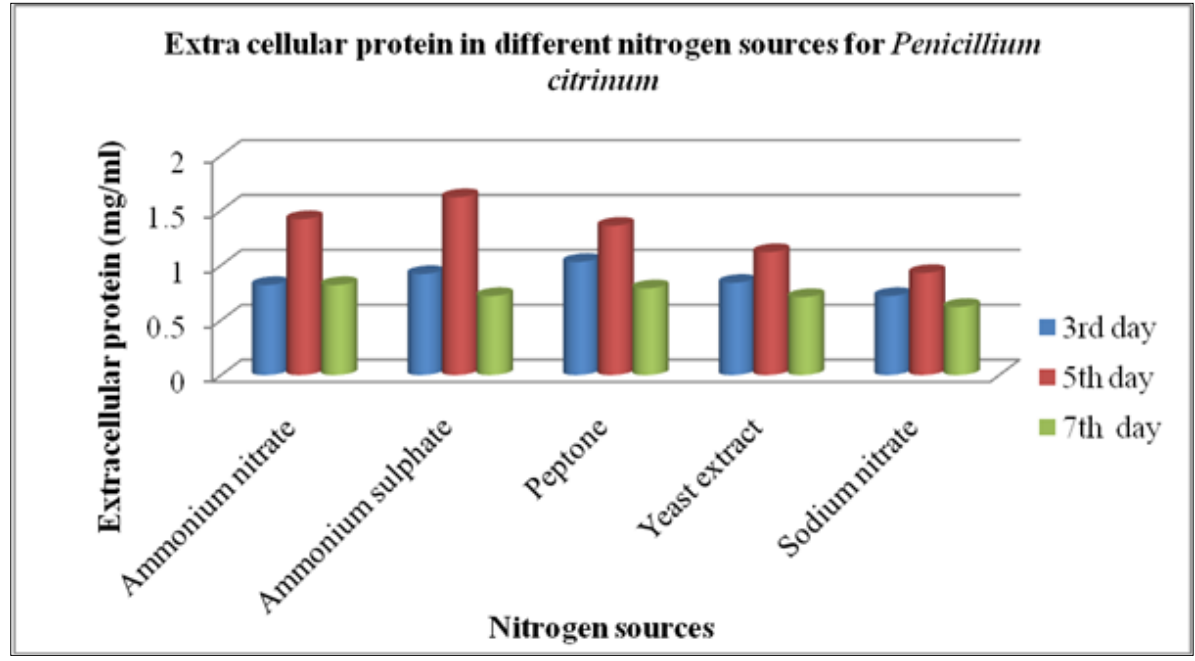

Figure 6. Extra cellular protein in different nitrogen sources for Penicillium citrinum 


\section{Cellulase Activity of Penicillium citrinum in Different pH}

The fungal cellulase activity was recorded in $3^{\text {rd }}, 5^{\text {th }}$ and $7^{\text {th }}$ day of fungal culture broth and the highest fungal cellulase activity was recorded in $5^{\text {th }}$ day. The maximum cellulase activity was recorded in $5^{\text {th }}$ day $\mathrm{pH}-6.0(86 \mathrm{U} / \mathrm{ml})$ followed by $\mathrm{pH}-5.5(71 \mathrm{U} / \mathrm{ml}), \mathrm{pH}-5.0(64 \mathrm{U} / \mathrm{ml})$ and $\mathrm{pH}-6.5(62$ $\mathrm{U} / \mathrm{ml}) \mathrm{pH}-7.0(24 \mathrm{U} / \mathrm{ml})$. Similarly maximum cellulase activity was recorded in $3^{\text {rd }}$ day $\mathrm{pH}-5.5(39 \mathrm{U} / \mathrm{ml})$ followed by $\mathrm{pH}-6.0(35 \mathrm{U} / \mathrm{ml}), \mathrm{pH}-6.5(35 \mathrm{U} / \mathrm{ml}), \mathrm{pH}-5.0(32$ $\mathrm{U} / \mathrm{ml})$ and $\mathrm{pH}-7.0(24 \mathrm{U} / \mathrm{ml})$. Minimum cellulase activity was recorded in $7^{\text {th }}$ day $\mathrm{pH}-6.5(37 \mathrm{U} / \mathrm{ml})$ followed by $\mathrm{pH}-$ $5.5(36 \mathrm{U} / \mathrm{ml}), \mathrm{pH}-6.5(32 \mathrm{U} / \mathrm{ml}), \mathrm{pH}-5.0(31 \mathrm{U} / \mathrm{ml})$ and $\mathrm{pH}-7.0(12 \mathrm{U} / \mathrm{ml})($ Fig -7$)$.

\section{Extra Cellular Protein Estimation of Penicillium citrinum for Different pH}

The estimation of extra cellular protein were recorded in $3^{\text {rd }}, 5^{\text {th }}$ and $7^{\text {th }}$ day of fungal culture broth and the highest extra cellular protein were recorded in 5th day. The maximum amount of extra cellular protein were recorded in $5^{\text {th }}$ day $\mathrm{pH}-6.0(0.88 \mathrm{mg} / \mathrm{ml})$ followed by $\mathrm{pH}-6.5(0.82$ $\mathrm{mg} / \mathrm{ml}), \mathrm{pH}-5.5(0.78 \mathrm{mg} / \mathrm{ml}), \mathrm{pH}-5.0(0.64 \mathrm{mg} / \mathrm{ml})$ and $\mathrm{pH}-7.0(0.64 \mathrm{mg} / \mathrm{ml})$. Similarly maximum amount of extra cellular protein were recorded in $3^{\text {rd }}$ day $\mathrm{pH}-5.5(0.61$ $\mathrm{mg} / \mathrm{ml})$ followed by $\mathrm{pH}-6.0(0.59 \mathrm{mg} / \mathrm{ml}), \mathrm{pH}-6.5(0.56$ $\mathrm{mg} / \mathrm{ml}), \mathrm{pH}-5.5(0.55 \mathrm{mg} / \mathrm{ml})$ and $\mathrm{pH}-7.0(0.42 \mathrm{mg} / \mathrm{ml})$. The minimum amount of extra cellular protein were recorded in $7^{\text {th }}$ day $\mathrm{pH}-6.0(0.64 \mathrm{mg} / \mathrm{ml})$ followed by $\mathrm{pH}-6.5(0.55$ $\mathrm{mg} / \mathrm{ml}), \mathrm{pH}-5.5(0.50 \mathrm{mg} / \mathrm{ml}), \mathrm{pH}-7.0(0.49 \mathrm{mg} / \mathrm{ml})$ and $\mathrm{pH}-5.0(0.37 \mathrm{mg} / \mathrm{ml})($ Fig -8$)$.

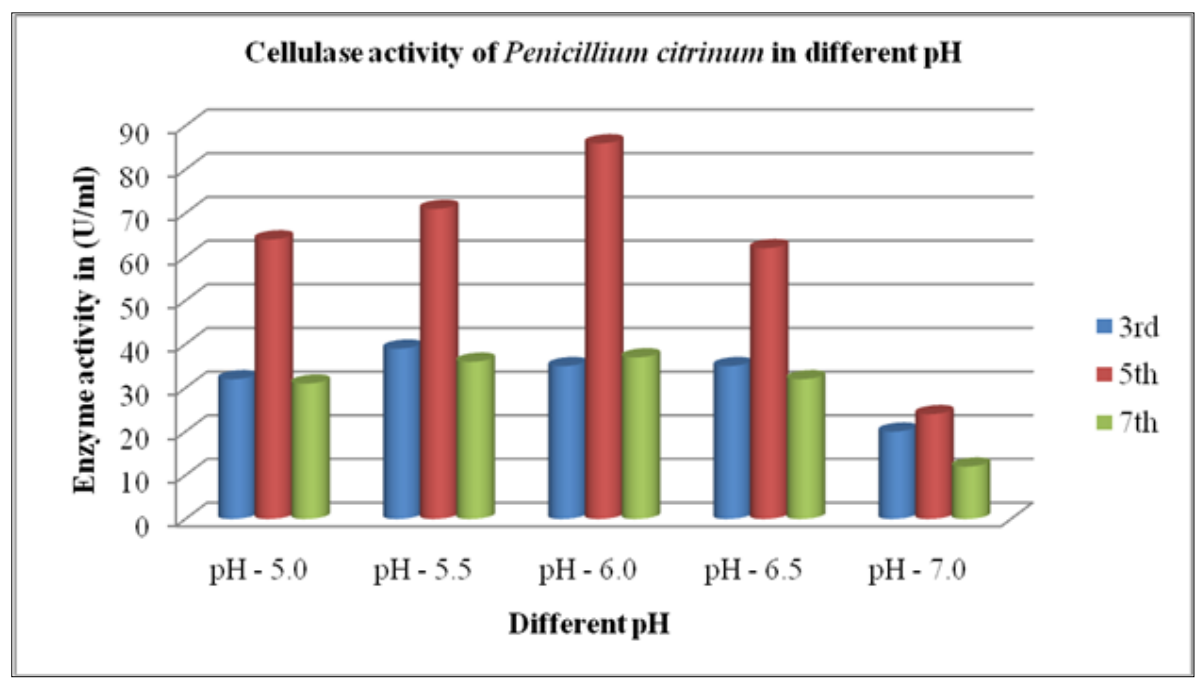

Figure 7. Cellulase activity of Penicillium citrinum in different $\mathrm{pH}$

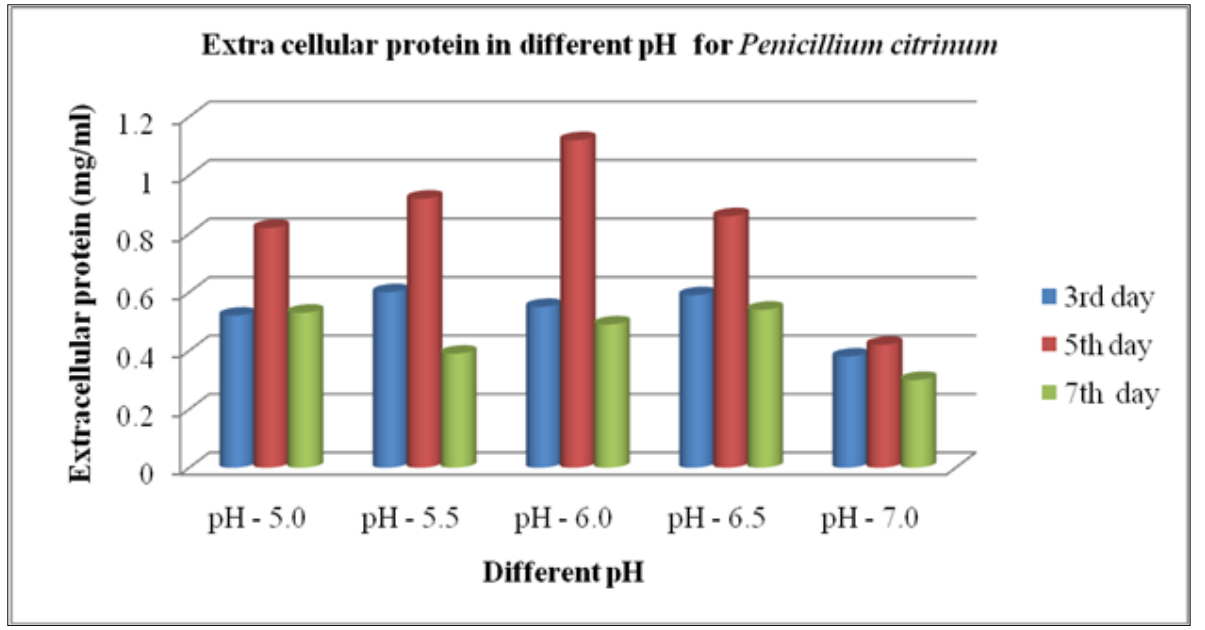

Figure 8. Extra cellular protein in different $\mathrm{pH}$ for Penicillium citrinum 


\section{Cellulase Activity of Penicillium citrinum in Different Substrate}

The fungal cellulase activity was recorded in $3^{\text {rd }}, 5^{\text {th }}$ and $7^{\text {th }}$ day of fungal culture broth and the highest fungal cellulase activity was recorded in $5^{\text {th }}$ day. The maximum cellulase activity was recorded in $5^{\text {th }}$ day wheat bran $(91 \mathrm{U} / \mathrm{ml})$ followed by rice bran $(88 \mathrm{U} / \mathrm{ml})$, paddy straw $(86 \mathrm{U} / \mathrm{ml})$, paddy husk $(71 \mathrm{U} / \mathrm{ml})$, and crude paper $(68 \mathrm{U} / \mathrm{ml})$. Similarly maximum result was recorded in $3^{\text {rd }}$ day wheat bran $(52 \mathrm{U} / \mathrm{ml})$ followed by rice bran $(49 \mathrm{U} / \mathrm{ml})$, paddy straw $(48 \mathrm{U} / \mathrm{ml})$, paddy husk $(41 \mathrm{U} / \mathrm{ml})$ and crude paper $(39 \mathrm{U} / \mathrm{ml})$. Minimum cellulase activity was recorded in $7^{\text {th }}$ day wheat bran (42 $\mathrm{U} / \mathrm{ml}$ ) followed by rice bran $(40 \mathrm{U} / \mathrm{ml})$, paddy husk (38 $\mathrm{U} / \mathrm{ml})$, paddy straw $(37 \mathrm{U} / \mathrm{ml})$ crude paper $(36 \mathrm{U} / \mathrm{ml})(\mathrm{Fig}$ -9).

\section{Extra Cellular Protein Estimation of Penicillium citrinum for different Substrates}

The estimation of extra cellular protein were recorded in $3^{\text {rd }}, 5^{\text {th }}$ and $7^{\text {th }}$ day of fungal culture broth and the highest extra cellular protein were recorded in 5th day. The maximum amount of extra cellular protein were recorded in $5^{\text {th }}$ day wheat bran $(1.12 \mathrm{mg} / \mathrm{ml})$ followed by rice bran $(1.04$ $\mathrm{mg} / \mathrm{ml})$, paddy straw $(1.03 \mathrm{mg} / \mathrm{ml})$, paddy husk $(0.93 \mathrm{mg} / \mathrm{ml})$ and crude paper $(0.89 \mathrm{mg} / \mathrm{ml})$. Similarly maximum amount of extra cellular protein were recorded in $3^{\text {rd }}$ day wheat bran $(0.71 \mathrm{mg} / \mathrm{ml})$ followed by rice bran $(0.68 \mathrm{mg} / \mathrm{ml})$, paddy straw $(0.62 \mathrm{mg} / \mathrm{ml})$, crude paper $(0.57 \mathrm{mg} / \mathrm{ml})$ and paddy husk $(0.54 \mathrm{mg} / \mathrm{ml})$. The minimum amount of extra cellular protein were recorded in $7^{\text {th }}$ day rice bran $(0.62 \mathrm{mg} / \mathrm{ml})$ followed by wheat bran $(0.59 \mathrm{mg} / \mathrm{ml})$ and paddy husk $(0.59$ $\mathrm{mg} / \mathrm{ml})$, paddy straw $(0.53 \mathrm{mg} / \mathrm{ml})$ and crude paper $(0.52$ $\mathrm{mg} / \mathrm{ml}$ ) (Fig -10).

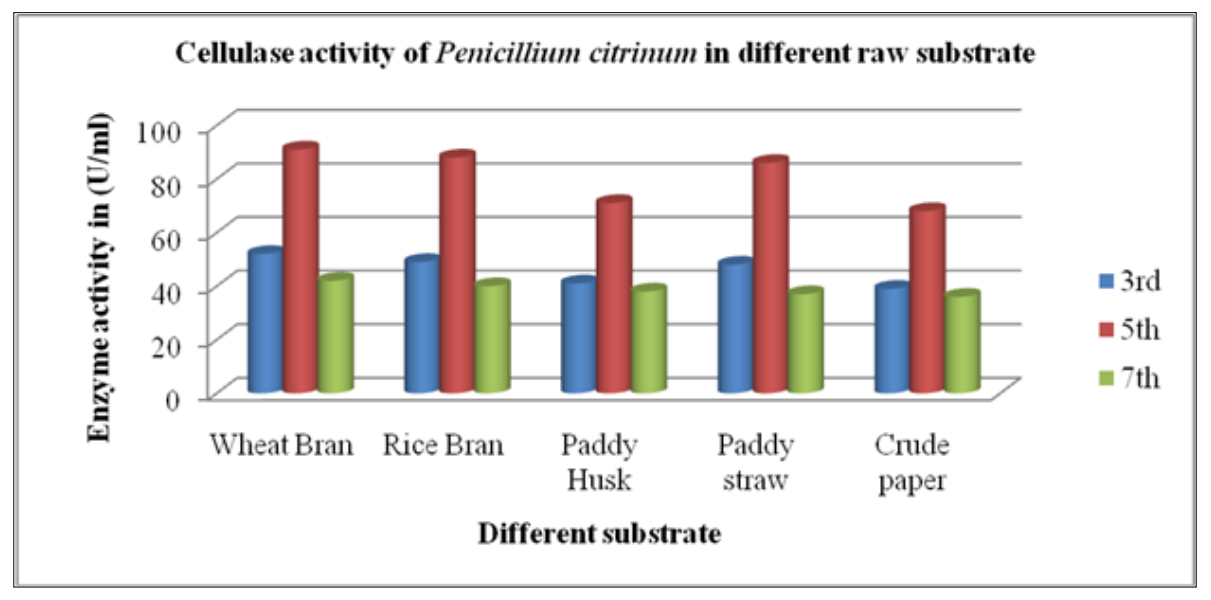

Figure 9. Cellulase activity of Penicillium citrinum in different substrate

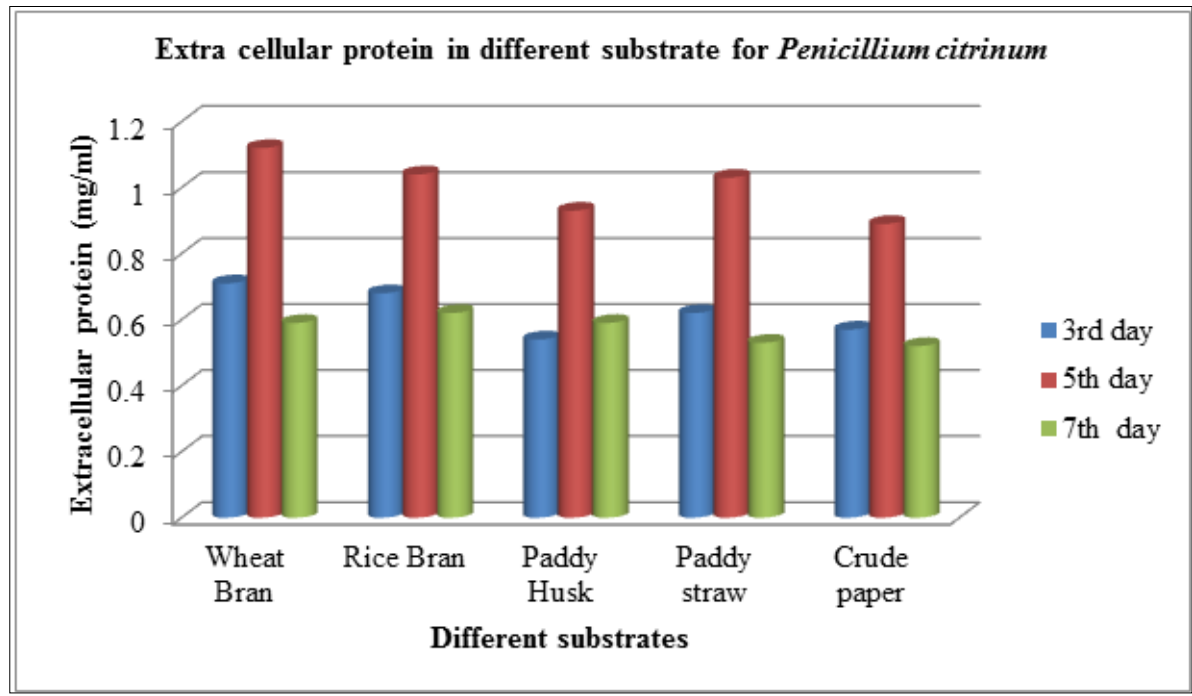

Figure 10. Extra cellular protein in different substrate for Penicillium citrinum 


\section{Discussion}

Fungi are not only beautiful but also play a significant role in the daily life of human beings besides their utilization in industry, agriculture, medicine, food industry, textiles, bioremediation, natural cycling, as biofertilizers and many other ways. Fungal biotechnology has become an integral part of the human welfare. Microorganism performs their metabolic processes rapidly and with remarkable specificity under ambient conditions, catalyzed by their diverse enzyme-mediated reactions. There is a wide spectrum of microorganisms which can produce the variety of enzymes like cellulase under appropriate conditions [31].

Emoghene [33] reported that cellulolytic fungal isolates Aspergillus niger, Aspergillus fumigatus, Penicillium citrinum, Penicillium chrysogenum isolated from decayed wood samples. In present study of fungal isolates Penicillium citrinum, recorded from Sathuragiri Hills samples. Sonia Sethi and Saksham Gupta [32] were reported that maximum enzyme activity was observed at $\mathrm{pH} 5.0$ for Penicillium chrysogenum $(0.95 \mathrm{U} / \mathrm{ml})$ and Aspergillus niger $(0.85 \mathrm{U} / \mathrm{ml})$. Gautam [31] reported that optimum $\mathrm{pH}$ for cellulase activities were found at $\mathrm{pH}$ 6.5. The enzyme activity was influenced by $\mathrm{pH}$ variation and depends on fungal species. Fungal enzyme also noted that the enzyme activity was stable at $\mathrm{pH}$ range of 5.0-8.0. Beldman [34] also reported that Aspergillus species grow and metabolize well in acidic $\mathrm{pH}$ medium between $\mathrm{pH} 3.0$-5.0. Latifian [35] and Wen [36] was reported in the production of most fungal cellulases in the $\mathrm{pH}$ range of 4.5-6.0. In present study maximum yield of cellulase enzyme recorded in the range of $\mathrm{pH}-5$ to $6.5 \mathrm{in}$ Penicillium citrinum $(86 \mathrm{U} / \mathrm{ml})$.

Muthuvelayudham and Viruthagiri [37] were reported that Cellulose $(78 \mathrm{U} / \mathrm{ml})$, glucose $(24 \mathrm{U} / \mathrm{ml})$, xylose $(28 \mathrm{U} / \mathrm{ml})$ and lactose $(28 \mathrm{U} / \mathrm{ml})$ is a best carbon source for the production of cellulase enzyme by Trichoderma reesei. Sonia Sethi and Saksham Gupta [32] were reported that glucose is a best carbon source for the production of cellulase enzyme by Penicillium sps $(0.60 \mathrm{U} / \mathrm{ml})$ and Aspergillus niger $(0.52 \mathrm{U} / \mathrm{ml})$. Gautam [31] reported that sucrose is a best carbon sources for the production of cellulose enzyme (exoglucanase $(2.68 \mathrm{U} / \mathrm{mL})$, endoglucanase $(2.17 \mathrm{U} / \mathrm{mL})$ and $\beta$-glucosidase $(2.06 \mathrm{U} / \mathrm{mL})$ in Aspergillus niger and Trichoderma sp. In present study maltose $(159 \mathrm{U} / \mathrm{ml})$ and glucose $(134 \mathrm{U} / \mathrm{ml})$ are the best carbon sources for the production of cellulase enzyme by Penicillium citrinum

Sonia Sethi and Saksham Gupta [32] were reported that ammonium sulphate is a best nitrogen source for the production of cellulase enzyme by Aspergillus niger and Penicillum citrinum. Gautam [31] were reported that Peptone $(2.40 \mathrm{U} / \mathrm{ml})$, Ammonium nitrate $(2.28 \mathrm{U} / \mathrm{ml})$ and beef extract $(1.99 \mathrm{U} / \mathrm{ml})$ is a best nitrogen source for the production of cellulase enzyme by Aspergillus niger. Sun [38] were reported that beef extract and peptone resulted in increased growth and enzyme production. In present study ammonium sulphate $(141 \mathrm{U} / \mathrm{ml})$ and ammonium nitrate $(121 \mathrm{U} / \mathrm{ml})$ are the best nitrogen source for the production of cellulase enzyme by Penicillium citrinum.

Muthuvelayudham and Viruthagiri [37] were reported that rice straw $(44 \mathrm{U} / \mathrm{ml})$ and sugar cane bagasse $(68 \mathrm{U} / \mathrm{ml})$ is a best substrate for the production cellulase enzyme by Trichoderma reesei. Padmavathi [39] reported that wheat bran $(20 \mathrm{U} / \mathrm{ml})$ and rice bran $(36 \mathrm{U} / \mathrm{ml})$ are the best substrate for the production cellulase enzyme by $M$. plumbeus. Sonia Sethi and Saksham Gupta [32] reported that coconut cake, ground nut cake, wheat bran and soy cake is the best substrates for the production of cellulase enzyme by Aspergillus niger and Penicillium chrysogenum. Ojumu [40] reported that saw dust, rice straw and sugarcane bagasse is a best substrates for the production of cellulase enzyme by Aspergillus flavus. Lian Xiong [41] reported that rice straw was produced highest cellulase activity was obtained. Baiget [42] reported that banana waste based medium for production of cellulolytic enzymes by $T$. lignorum. Ananda Muniswaran et al., [43] used banana stalk and coconut coir for production of cellulases by Aspergillus niger and Penicillium sp. In present study wheat bran $(91 \mathrm{U} / \mathrm{ml})$ and rice bran $(81 \mathrm{U} / \mathrm{ml})$ is a best substrate for the production of cellulase enzyme by Penicillium citrinum

Mohammed InuwaJa'afaru, [44] reported that Aspergillus ustus, Trichoderma sp. Trichoderma sp. Aspergillus ustus, and Trichoderma viride activity of cellulose enzyme level were increased simultaneously extra cellular protein level also increased. Muthuvelayudham and Viruthagiri [37] reported that production of extra cellular protein in different carbon source such as Cellulose $(9.74 \mathrm{mg} / \mathrm{ml})$, glucose $(1.78$ $\mathrm{mg} / \mathrm{ml})$, xylose $(8.02 \mathrm{mg} / \mathrm{ml})$ and lactose $(7.98 \mathrm{mg} / \mathrm{ml})$ were recorded in micro-fungal species Trichoderma reesei, alteration of carbone sources influence in alteration of extra cellular protein. Nwodo-Chinedu, et al., [45] reported that for extra cellular protein from fungal isolates for $A$. flavus $(0.7 \mathrm{mg} / \mathrm{ml})$ A. niger $I(1.5 \mathrm{mg} / \mathrm{ml})$ A. niger $I I(1.0 \mathrm{mg} / \mathrm{ml}) B$. cinerea $(1.4 \mathrm{mg} / \mathrm{ml})$ Penicillium species $(1.0 \mathrm{mg} / \mathrm{ml})$. Similarly in present study extracellular protein is also recorded in Penicillium citrinum $(1.63 \mathrm{mg} / \mathrm{ml})$ for maltose followed by ammonium sulphate $(1.62 \mathrm{mg} / \mathrm{ml})$, yeast extract $(1.12 \mathrm{mg} / \mathrm{ml})$ at $\mathrm{pH}-6$, wheat bran $(1.12 \mathrm{mg} / \mathrm{ml})$.

\section{Conclusions}

Micro-fungal cellulase production rate depends on three important parameters such as $\mathrm{pH}$, carbon, Nitrogen substances, which was used to alter the cellulase production in micro-fungal species. The present study focus on cheapest substrate used to improve the cellulase activity and is very important in industrial scale up of cellulase production rate.

\section{Acknowledgements}

The facilities provided by Department of Biotechnology, 
Ayya Nadar Janaki Ammal College, Sivakasi to carry out this study are gratefully acknowledged. The author also thanks UGC-SERO for providing financial support to carry out the project under Minor Research Project (MRP-5777/15).

\section{REFERENCES}

[1] Bari, M.A., Begum, M.F. Sarker, K.K. Rahma, M.A. Kabir, A.H. and Alam, M.F. 2007. Mode of action of Trichoderma spp. on organic solid waste for bioconversion. Plant Environ. Develop., 1: 61-66.

[2] Damisa, D., Amen, J.B. and Edge, N.E.L. 2011. Cellulase Production by native Aspergillus niger obtained from soil environments. Journal of Fermentation Technology and Bioengineering 1:62-70.

[3] Buzzini, P. and Martini, A. 2002. Extracellular enzymatic activity profiles in yeast and cassava waste dumpsite in Minna, Niger State, Nigeria. African Journal of Microbiology Research 3 (4): 143-146.

[4] Sathyaprabha, G., Panneerselvam, A. and Muthukumarasamy, S. 2011. Production of Cellulase and Amylase from wild and mutated fungal isolates. E-Journal of Life Sciences 1(1): $39-45$

[5] Arunsasi., Kani, M. Panneerselvam, A. Jegadeesh, G. Muthu, K. and Kumar, M.R. 2010. Optimizing the conditions of $\alpha$ amylase by an estuarine strain of Aspergillus spp. African Journal of Microbiology Research 4 (8): 581-586.

[6] Naveenkumar, K.J. and Thippeswamy, B. 2013. "Isolation and screening of potential cellulolytic fungi from Areca nut husk waste." Int J Curr Sci, 8: E 125-132.

[7] Jahangeer, S., Khan, N. Jahangeer, S. Sohail, M. Shahzad, S. Ahmad, A. and Khan, S.A. (2005). "Screening and characterization of fungal cellulases isolated from the native environmental source.” Pak. J. Bot. 37, 739-748.

[8] Abo-State, M.A.M., Hammad, A.I. Swelin, M. and Gannam, R.B. 2010. "Enhanced production of cellulases by Aspergillus spp. isolated from agriculture wastes by solid state fermentation," American-Eurasian Journal of Agricultural \& Environmental Science, vol. 8, pp. 402-410, 2010.

[9] Tao, Y.M., Zhu, X.Z. Huang, J.Z. Ma, S.J. Wu, X.B. Long, M.N. and Chen, Q.X. 2010. "Purification and properties of endoglucanase from a sugarcane bagasse hydrolyzing strain, Aspergillus glaucus XC9," J. Agric. Food Chem. 58(10), 6126- 6130

[10] Olsson L., Hahn-Hagerdahl B. 1997. Fermentation of lingocellulose hydrolisates for ethanol production. Enzyme Microb. Technol.18, P. 312-331

[11] Levy I., Shani Z., Shoseyov O. 2002. Modification of polysaccharides and plant cell wall by endo-1, 4-b-glucanase and cellulose-binding domains. Biomolecular Engineering. 19. P. 17-30.

[12] Van Wyk J. P. H., Mohulatsi M. 2003. Biodegradation of waste-paper by cellulose from Trichoderma viride.
Bioresource Technology. 86, P. 21-23.

[13] Luo J., Xia L. M., Lin J. P., Cen P. L. 1997. Kinetics of simultaneous saccharification and lactic acid fermentation processes. Biotechnol. Progr. 1: 762-767

[14] Oksanan T., Peeabilaniana J. 1998. Alkaline detergent enzymes from alkaliphilic enzymatic properties, genetics and structures. Extremophiles. 2(3): 185-190.

[15] Oksanen, T.J., Pere, I. Paavilainen, I. Buchert, I. and Viikari I. 2000.The enzymatic degradation of waste cellulose by fungal enzymes.J. Biotechnol., 78: 39-48.

[16] Suurnäkki A., Niku-Paavola M-L., Buchert J., Viikari L. 2004. Enzymes in pulp and paper processing. In: Aehle W. (ed.). Enzymes in Industry. Weinheim, Wiley-VCH. P. 232-244, 437-439.

[17] Nierstrasz V., Warmoeskerken M. 2003. Process engineering and industrial enzyme applications. In: Cavaco-Paulo A., Gubitz G. (eds.). Textile Processing with Enzymes. England, Woodhead Publishing Ltd. P. 120-157.

[18] Miettinen-Oinonen A., Londesborough J., Joutsjoki V., Lantto R., Vehmaanperä J. 2004. Three cellulases from Melanocarpus albomyces with applications in the textile industry. Enzyme and Microbial Technology. Vol. 34. P. 332-341.

[19] Penttilä M., Limon C., Nevalainen H. 2004. Molecular biology of Trichoderma and biotechnological applications. In: Arora D. (ed.). Handbook of fungal biotechnology. Marcel Dekker, Inc. P. 413-427.

[20] Urlaub R. 2002. Enzymes in fruit and vegetable juice extraction. In: Whitehurst R., Law B. (eds.) Enzymes in food technology. Sheffield, Academic Press, CRC Press. P. 145183

[21] Van Wyk J. P. H., Mohulatsi M. 2003. Biodegradation of waste-paper by cellulose from Trichoderma viride Bioresource Technology. Vol. 86. P. 21-23.

[22] Bhat, M.K. 2000. "Cellulases and related enzymes in biotechnology," Biotechnol Adv, 18 (2000) 355-385.

[23] Lynd, L.R., Weimer, P.J. Vanzyl, W.H. and Pretorius, I.S. 2002. Microbial cellulose utilization: fundamentals and biotechnology, Microbial Mol Boil Rev, 66:506-577.

[24] Ortega N., Busto M. D., Perez-Mateos M. 2001. Kinetics of cellulose saccharification by Trichoderma reesei cellulases. International Biodeterioration and Biodegradation. Vol. 47. P. 7-14.

[25] George, B. The Genera of Hyphomycetes from Soil, 1972. Publisher: Robert E. Krieger Publishing Co., Box 542, Huntington, NY 11743.

[26] Domsch, K.H., Gams, W. and Anderson T.H. 1980. Compendium of Soil Fungi.vol. 1 and 2, Academic Press, London.

[27] Shukla, P. and Gupta, K. 2007. Ecological screening for Lipolytic molds and process optimization for lipase production from Rhizopus oryzae KG-5.Journal of applied sciences in environmental sanitation, 2(2):35-42.

[28] Sherief, A.A. El-Tanash, A.B. and Atia, N. 2010. "Cellulase production by Aspergillus fumigatus grown on mixed 
substrate of rice straw and wheat bran." Research Journal of Microbiology. 5 (3): $199-211$.

[29] Miller, G.L. 1959. "Use of dinitrosalicylic acid reagent for determination of reducing sugar."Analytical Chemistry. 31: 426-428.

[30] Lowry O.H, Rosebrough N.J, Farr A. et al. "Protein measurement with folin phenol reagent."J BiolChem. 1951; 193: 265-275.

[31] Gautam, S.P., Bundela, P.S. Pandey, A.K. Awasthi M.K. and Sarsaiya, S. 2010. Composting of Municipal Solid Waste of Jabalpur Cit. Global J. Environ. Resea. 4(1):43-46

[32] Sonia Sethi and Saksham Gupta, 2014. "Optimization of cultural parameters for cellulase enzyme production from fungi." Biolife, 2(3): 32-44

[33] Emoghene A.O., Okungbowa, O.C. Obayagbona, O.N. and Jaboro, A.G. 2014. "Cellulolytic activities of wild type fungi isolated from decayed wood cuttings." Nig J. Biotech. 27: $41-48$.

[34] Beldman, G., Searle-Van, L.M.F. Rombouts, F.M. and Voragen, F.G.J. 1985. The celulase of Trichoderma virde: Purifcation, characterization and comparison of al detectable endoglucanases, exoglucanase and B-glucidase. Eur $J$ Biochem. 146:301-308.

[35] Latifian, M., Hamidi-Esfahani, Z. and Barzegar, M. 2007. "Evaluation of culture conditions for cellulase production by two Trichoderma reesei mutants under solid-state fermentation conditions.” Bioresour. Technol., 98: 3634 3637.

[36] Wen, Z.Y., Liao, W. and Chen, S.L. 2005. "Production of cellulase by Trichoderma reesei from dairy manure." Bioresour. Technol., 96: 491 - 499

[37] Muthuvelayudham, R. and Viruthagiri, T., 2006. "Fermentative production and kinetics of cellulase Protein on Trichoderma reesei using sugarcane bagasse and rice straw." African Journal of Biotechnology Vol. 5 (20), pp. 1873-1881.
[38] Sun, T., Liu, B.H., Li, Z.H. and Liu, D.M., 1999."Effect of air pressure amplitude on cellulase production by Trichoderma viride SL1 in periodic pressure solid state fermentation."Process Biochemistry, 34, pp 2529.

[39] Padmavathi.T, Vaswati Nandy and Puneet Agarwal 2012. "Optimization of the medium for the production of cellulases by Aspergillus terreus and Mucor plumbeus." European Journal of Experimental Biology, 2 (4):1161-1170.

[40] Ojumu, T.V., Solomon, B.O. Betiku, E. Layokun, S.K. and Amigun, B. 2003. Cellulase production by Aspergillus flavus Linn isolate NSPR 101 fermented in sawdust, bagasse and corncob. Afr. J. Biotechnol., 2(6): 150-152.

[41] Lian Xiong, Chao Huang, Wan-feng Peng, Lv-rong Tang, Xiao-yan Yang, Xue-fang Chen, Xin-de Chen, Long-long Ma, and Yong Chen, 2013. "Efficient cellulase production from low-cost substrates by Trichoderma reesei and its application on the enzymatic hydrolysis of corncob." Vol. 7(43), pp. 5018-5024.

[42] Baige, M.M.V., et al. 2003. Utilization of agricultural waste of banana: production of cellulases by soil fungi, J. Environ. Biol., 24: 173- 176.

[43] Ananda Muniswaran, P.K., Selvakumar, P. and Narasimha Charyulu, N.C.L. 1994. Production of cellulases from coconut coir pith in solid state fermentation.J. Chem. Technol. Biotechnol., 60: 147-151.

[44] Mohammed Inuwa Ja'afaru, 2013. "Screening of Fungi Isolated from Environmental Samples for Xylanase and Cellulase Production.” ISRN Microbiology Volume 2013, Article ID 283423

[45] Nwodo-Chinedu, V.I. Okochi, H.A. Smith and O. Omidiji 2005." Isolation of Cellulolytic Microfungi Involved in Wood-Waste Decomposition: Prospects for Enzymatic Hydrolysis of Cellulosic Wastes." International Journal of Biomedical and Health Sciences, 1(2): 456-469. 